\author{
I.I. Сєряков ${ }^{1}$, O.I. Пономарьов ${ }^{1}$, C.М. Бабкін ${ }^{1}$ \\ ${ }^{1}$ Державний науково-дослідний інститут авіащії, Київ
}

\title{
ОСНОВНІ ТЕНДЕНЦІЇ РОЗВИТКУ АВІАЦІЙНИХ ВИСОКОТОЧНИХ БОЄПРИПАСІВ МАЛОГО КАЛІБРУ
}

\begin{abstract}
У статті, на основі аналізу матеріалів закордонних інформаційних джерел, розглянуто призначення, конструктивні особливості, основні тактико-технічні характеристики та переваги сучасних й перспективних зразків авіаційних керованих засобів ураження малого калібру класу “повітря - поверхня”, які знаходяться або плануються до прийняття на озброєння авіації у провідних країнах. За результатами аналізу демонструються основні тендениії розвитку ц̧ього класу зброї.
\end{abstract}

Ключові слова: бойова авіація, авіаџійна керована ракета, головка самонаведення, система наведення, керована авіаційна бомба.

\section{Вступ}

Постановка проблеми. Авіаційна високоточна зброя за кілька останніх десятиліть сформувалася у самостійний вид озброєння, що бурхливо розвивається у світі на основі використання нових високих технологій. За поглядами військового керівництва провідних зарубіжних країн бойова авіація повинна бути здатна забезпечити одночасне ураження безлічі стаціонарних та мобільних цілей за рахунок прийняття на озброєння авіаційних високоточних засобів ураження малого калібру (до 120 кг).

Аналіз останніх досліджень і публікацій. Питанню розвитку авіаційних високоточних боєприпасів малого калібру присвячена певна кількість наукових публікацій, зокрема в них розглядаються можливі варіанти розвитку авіаційних високоточних боєприпасів малого калібру [1]. Але в зазначених публікаціях не в повному обсязі проведен аналіз цього класу зброї. Для розкриття тенденцій розвитку авіаційних високоточних боєприпасів малого калібру необхідно провести остатковий аналіз.

Мета статті. На основі аналізу основних тактико-технічних характеристик іноземних зразків авіаційних високоточних боєприпасів малого калібру необхідно розкрити основні тенденції розвитку цього класу зброї.

\section{Виклад основного матеріалу}

Традиційно в керованих боєприпасах малого калібру мала потребу авіація сил спеціальних операцій (ССО) і армійська авіація, а 3 появою безпілотних літальних апаратів їх оснащення такими боєприпасами стало особливо актуальним.

Керовані авіаційні бомби є одним 3 найбільш ефективних видів авіаційної зброї, призначеним для нанесення ударів по наземним (надводним) цілям.
Літаки стратегічної бомбардувальної авіації також стали оснащувати керованою авіаційною зброєю малого калібру. В даний час американський стратегічний бомбардувальник В-2A, оснащений керованими авіаційними бомбами (КАБ) GBU-39/B калібру 250 фунтів (113 кг), здатний 3 високою точністю завдавати удари одночасно по 64 цілям в будь-яких метеоумовах, В-1В - по 96, а тактичні винищувачі F-22A і F-35 - по 8 і 16 відповідно. Очікується, що до 2030 року більшість засобів бойової авіації провідних зарубіжних країн зможуть вражати стаціонарні і мобільні об'єкти 3 першої атаки, в тому числі без входу в зону ураження активних засобів ППО супротивника. Це дозволить наносити противнику значний збиток з мінімальним ризиком для своїх сил [2, 3].

У КАБ висока вражаюча здатність бойової частини поєднується 3 точністю наведення, що властиво керованим ракетам класу “повітря-земля". Значна дальність КАБ дозволяє застосовувати їх без заходу літаків-носіїв в зону дії ППО супротивника. При цьому область можливого скиду бомби 3 великих висот лише незначно поступається зоні дальньої межі пуску ракети. При однаковій стартовій масі і дальності пуску (скидання) КАБ більш ефективно вражає ціль. Останні військові конфлікти в Іраку, Афганістані та Лівії показали, що $68 \%$ від всього арсеналу використаної керованої зброї склали КАБ. У порівнянні з ракетами керовані бомби коштують набагато дешевше [4].

У 2006 році на озброєння авіації США була прийнята КАБ GBU-39/B, розроблена в рамках першого етапу програми SDB I. Бомба призначена для ураження стаціонарних і мобільних наземних цілей на дальності до 100 км. КАБ GBU-39/B має крило, що розкривається після іï скидання, оснащена комбінованою системою наведення інерціальної навігаційної системи 3 корекцією за даними супутникової радіо навігаційної системи "Навстар" [5]. Проникаюча бойова частина може 
пробити залізобетонне укриття товщиною до 2 м. Невеликі маса (113 кг) та габарити КАБ (довжина 2,7 м, діаметр 0,15 м) дозволяють підвішувати іiї у внутрішні відсіки літаків F-22A i на зовнішні підвіски БпЛА "Хантер", "Предатор", "Ріпер" і "Грей Ігл". Крім того, такими КАБ оснащені стратегічні бомбардувальники В-52Н, В-2А і В-1B, а в перспективі вона увійде до складу номенклатури озброєння тактичного винищувача F-35 (загальна кількість 16 штук).

3 метою подальшого збільшення можливостей КАБ сімейства SDB по ураженню стаціонарних i мобільних цілей фахівці фірми “Рейтеон” в рамках другого етапу програми SDB II розробляють керовану авіаційну бомбу GBU - 53/B [6]. Особливістю цієї КАБ є комбінована система наведення, яка складається 3 інерціальної навігаційної системи, перешкодостійкого приймача супутникової радіо навігаційної системи "Навстар" i засобів лінії передачі даних “Лінк-16", а також трьох-режимну головку самонаведення (ГСН), працюючу в оптичному, міліметровому і інфрачервоному (неохолоджуваний датчик) діапазонах довжин хвиль. Крім того, КАБ буде оснащена крилом, що складається, ефективною БЧ і багатофункціональним програмованим детонатором L-3. Дана КАБ, маса якої складає 93 кг, поступила на озброєння у 2017 році. Носіями бомби стали літаки F-15E, F-22A і F-35B і C, а також літаки - F-16, F-35A, B-2A, A-10C, B-1B, B-52H, F/A-18E/F i безпілотні літальні апарати (БпЛА) МQ-9. Бомба підвішується на універсальному балковому утримувачі BRU-61/A. Попереднє замовлення на такі бомби становить близько 17200 одиниць, при цьому вартість однієї складає близько 270 тис. доларів США.

На озброєння літака КС-130Ј морської піхоти надходить модернізований варіант самонавідного боєприпасу GBU-44/ B “Вайпер Страйк”, який здатний вражати мобільні цілі противника.

Можливість вражати мобільні цілі 3'явилася після модернізації програмного забезпечення попередньої версії боєприпасу. Його система наведення складається 3 інерціальної навігаційної системи (IHC) 3 корекцією за даними супутникової радіонавігаційної системи "Навстар" i напівактивною лазерною ГСН. Маса кумулятивної БЧ 2,72 кг.

У Франції в 2007 році була прийнята на озброєння керована авіаційна бомба AASM, яка призначена для ураження малорозмірних цілей. Маса КАБ 125 кг, іiї система наведення включає IHC 3 корекцією за даними супутникової радіонавігаційної системи "Навстар" [8] i тепловізійну або лазерну ГСН. При цьому точність наведення становить 10..15 м. Дальність застосування бомби знаходиться в діапазоні $15 . .60$ км в залежності від висоти польоту носія. КАБ АASM замінила застарілу керовану ракету AS-30L. У 2010 році вперше було здійснено скидання AASM, оснащеної лазерною ГСН. В результаті випробування, в якому в якості носія використовувався винищувач “Рафаль", була вражена нерухома ціль на дальності 25 км, підсвічена за допомогою цілевказівника DHY-307, при цьому точність наведення склала 1 м. Траєкторія кінцевої ділянки наведення була вертикальною, що дає можливість гарантованого ураження цілі і зводить до мінімуму ризик супутніх руйнувань. Крім того, наявність напівактивної лазерної ГСН дозволить використовувати КАБ по мобільних цілях.

У лютому 2010 року фірмі “Сажем" було замовлено 380 лазерних ГСН. Розгортання варіанту 3 лазерним наведенням відбулось в 2013 році.

Нова версія КАБ ААSM - SBU-54, що має ІЧ ГСН, з липня 2011 року поступає на озброєння авіації Франції [8]. Вона успішно пройшла випробування в бойових умовах. Система наведення цієї бомби складається 3 ІЧ ГСН, розташованої в головній частині, а також IHC 3 корекцією за даними супутникової радіо навігаційної системи "Навстар".

Наявність такої системи наведення дозволяє застосовувати ці бомби по цілях 3 невідомими координатами. Бойові дії в Лівії показали, що за допомогою SBU-54 можна знищувати цілі, які раніше вражались крилатими ракетами. Крім того, КАБ АASM здатна виводити з ладу засоби ППО супротивника, при цьому носій здійснює скидання бомби, не входячи в зону дії ППО. Керована авіаційна бомба малого калібру SABER $є$ розробкою європейського концерну MBDA. Вона призначена для ураження легкоброньованих, а також броньованих цілей противника. Очікується, що даною КАБ оснащуватимуться БПЛА зі злітною масою більше 100 кг.

SABER оснащена крилом, що збільшує дальність ऑï польоту до $10 \ldots 12$ км. До складу комбінованої системи наведення КАБ входять інерційна система наведення, кориговані за сигналами супутникової радіонавігаційної системи "Навстар" (середня ділянка траєкторії) i напівактивна лазерна ГCH (кінцева ділянка польоту). Крім того, замість лазерної ГСН може бути встановлена телевізійна або інфрачервона ГСН. Дворежимна бойова частина оснащена осколково-фугасним або кумулятивним зарядом. КАБ розроблена у двох варіантах: без силової установки (маса 4,5 кг) і 3 ракетним двигуном, адаптованим для пуску з малих висот (маса 13,6 кг). КАБ пройшла льотні випробування в Іраку.

Керована авіаційна бомба FT-5, розроблена китайськими фахівцями, призначена для ураження стаціонарних цілей. Система наведення бомби складається 3 IHC i 3 корекцією за даними супутникової радіо навігаційної системи “Бейдоу", при цьому точність наведення складає $15 \ldots 30$ м. Скидання КАБ здійснюється 3 висоти 
5000...12000 м. Основні характеристики FT-5: маса БЧ 35 кг; максимальна дальність 35 км; довжина 1,5 м; діаметр 0,2 м; носій - БпЛА.

В якості зразків подібної зброї розглянемо універсальні керовані ракети.

В даний час спеціалісти фірми “ЛокхідМартін” розробили малогабаритну керовану ракету “Скорпіон”, яка призначена для ураження живої сили супротивника, легкоброньованої техніки, вантажних і легкових автомобілів, а також вогневих позицій артилерії і мінометів. Висока точність наведення (ймовірне відхилення до 1 м) і наявність невеликої бойової частини (БЧ) масою 2,27 кг (можливий варіант 3 масою БЧ, рівної 7,7 кг) дозволяє задіяти цю ракету проти цілей, де потрібний низький рівень супутніх руйнувань.

Ракета "Скорпіон” може застосовуватися 3 різних пускових пристроїв, наприклад 3 підвісних пілонів М-299/М-310, що використовуються для пуску AGM-114 “Хеллфайр" $з$ гелікоптерів і 3 безпілотних літальних апаратів MQ-1 "Предатор" [9].

При використанні системи М-299/М-310 можлива підвіска на одній рейковій направляючій трьох ракет “Скорпіон” замість однієї АGM-114 “Хеллфайр”. Стартова маса “Скорпіон” 15,88 кг, довжина 0,546 м, діаметр 0,1 м, дальність стрільби до 18,5 км. На ракеті встановлена комбінована система наведення - напівактивна лазерна $Г \mathrm{CH}$, активна (міліметрового діапазону довжини хвилі) i тепловізійна (ТПВ) ГСН. Ракета “Скорпіон” була розроблена в інтересах авіації сухопутних військ і $\mathrm{CCO}$.

32010 року у збройні сили США поставляється малогабаритна керована ракета "Гріффін" фірми “Рейтеон”. Вона призначена для знищення стаціонарних і мобільних наземних цілей, в тому числі при наданні безпосередньої авіаційної підтримки в ході ведення бойових дій в населених пунктах.

До складу “Гріффін” входить: ракетний двигун твердого палива (РДТП) з системою управління; передня секція 3 напівактивною лазерною ГСН i програмованим підривачем; центральна секція, в якій розташована осколково-фугасна бойова частина і бортова апаратура, включаючи інерційну систему наведення з корекцією за даними супутникової радіо навігаційної системи “Навстар” [10].

Пуск ракети здійснюється 3 використанням портативного блоку керування вогнем, куди входить: приймач супутникової радіонавігаційної системи“Навстар", широкодіапазонна система 3в'язку PRC-117 і інтерфейси зв'язку: з пусковою установкою та радіочастотний 3 боєприпасом. Оператор задає географічні координати цілі, і при залповому пуску може забезпечуватися одночасний підхід до неї декількох ракет.

Розроблено дві модифікації ракети: "Гріффін" “A” і “B”. Перша (стартова маса - 15,7 кг, БЧ - 6 кг, довжина - 1,09 м, діаметр - 0,14 м) оптимізована для скидання через вантажну рампу літаків АС-130Н та U “Спектр” і “Спукі”, а також з оснащених знімним комплектом прицільної апаратури та озброєння “Дрегон Спір” багатоцільових літаків ССО МС$130 \mathrm{~W}$ “Комбат Спір”. Друга модифікація (стартова маса - 13 кг, маса БЧ - 3,6 кг, довжина - 0,99 м, діаметр - 0,14 м) виконана в транспортно-пусковому контейнері, що забезпечує іiі застосування 3 зовнішніх підвісок бойових гелікоптерів. В даний час розробники керованої авіаційної зброї малого калібру розглядають ідею створення мікробоєприпасів, які могли б застосовуватися 3 БпЛА малих розмірів.

У США в рамках програми JAGM розробляється протитанкова керована ракета (ПТКР). Вона буде призначена для ураження всіх типів мобільних і стаціонарних цілей противника, незалежно від погодних умов. Передбачається, що ця ракета замінить існуючі ПТКР AGM-114 "Хеллфайр", “Тоу” і керовану ракету загального призначення AGM-65 “Мейверік”. Програмою передбачена розробка єдиного варіанту ПТКР, оснащеного багатофункціональною БЧ. Носіями ракети будуть літаки, гелікоптери і БпЛА [11].

Особливістю даної ПТКР стане комбінована система наведення. Вона буде складатися 3 напівактивної лазерної ГСН (для ураження одиночних цілей з мінімальним побічним ефектом); інфрачервоної ГСН (пасивний режим роботи) i радіолокаційною ГCH міліметрового діапазону (активний режим роботи буде використовуватися при поганих метеоумовах, а також в умовах диму або пилу на полі бою). Крім того, передбачається можливість здійснення корекції наведення ракети під час польоту за даними від інших джерел інформації, ракету планується оснастити багатофункціональною бойовою частиною кумулятивною, проникаючою i фугасною. За допомогою кумулятивної БЧ ракета буде вражати більшість броньованих цілей, а 3 допомогою проникаючої та фугасної - кораблі, будівлі, бункери та інші укріплені цілі. Проникаюча БЧ забезпечить проникнення ракети всередину об'єкта, а фугасна буде вибухати вже всередині його. Дальність стрільби даної ракети складе 45 км.

Передбачається, що на початковій стадії для $\mathrm{CB}, \mathrm{BMC}$ придбають біля 35 тис. керованих ракет JAGM, а загальна кількість закуповуваних ракет може досягти 100 тис. одиниць [12]. Повна вартість програми складе 7 млрд. доларів. Носіями ракети будуть гелікоптери AH-64D “Апач Лонгбоу”, АН-1 
“Супер Кобра”, МН-60 “Сi Хок”, літак F/A-18 i, багатоцільові БПЛА MQ-1C “Грей Ігл”. В якості потенційного носія ПТКР JAGM розглядається тактичний винищувач F-35.

В кінці 2013 року концерн MBDA представив модифікацію ракети під назвою Brimstone-2 поліпшена версія ракети 3 дворежимною системою пошуку. Метою цієї модернізації було збільшення дальності стрільби, а також збільшення можливостей ракети при атаці рухомих об'єктів. Завдяки новому ракетному двигуну, максимальна дальність польоту була збільшена до 60 км (до 40 км при запуску з вертольота). Ракета оснащена новою БЧ більшої потужності і більш стійка до детонації під дією зовнішніх впливів. Багаторежимна система пошуку була модифікована, та отримала активний i пасивний канал. Завдяки цьому багаторежимна система пошуку здатна знаходити і відстежувати високо швидкісні й маневрені наземні цілі, в тому числі зі зниженою радіолокаційною помітністю. Пасивна система лазерного наведення із зовнішнім підсвічуванням цілі, реалізований в першій базової версії цієї ракетної пускової установки, також збереглась.

Нова керована ракета (КР) JAGM розроблена на основі американської протитанкової керованої ракети (ПТКР) AGM-114R “Хеллфайр”, має 3 нею багато загальних конструктивно-схемних рішень. AGM-114R “Хеллфайр” $\epsilon$ новою зброєю, яку передбачається використовувати у сучасних бойових операціях ЗС США та їхніх союзників на РДТП спільно 3 іншими високоточними боєприпасами. Ракета JAGM буде сумісна 3 існуючими пристроями підвіски та пуску на різних літальних апаратах (літаках, бойових вертольотах та ударних БпЛА).

Високоточна єдина уніфікована міжвидова ракета класу “повітря - поверхня" JAGM виконана за нормальною аеродинамічною схемою, розміщується на пілотованих та безпілотних ударних літальних апаратах. Вона призначена для знищення стаціонарних або високопріоритетних точкових наземних i надводних цілей, що рухаються, на дальності до 30 км (у перспективі дальність бойового застосування КР може зрости до 45 км). На ракеті використовується однокамерний РДТП підвищеної тяги із зарядом малодимного пороху, що забезпечує надзвукову швидкість і1і польоту. Рішення про розробку УР JAGM iз збільшеною дальністю пов'язане 3 переходом збройних сил США на нові прицільні системи MTADS (Modernized Target Acquisition Designation Sight), які дозволяють пілотам виявляти цілі на більшій відстані. При цьому льотчик із кабіни літака-носія зможе вибирати вид підриву бойової частини (комулятивний або осколково-фугасний).
Бронепробійність кумулятивної БЧ КР JAGM становить $1300 \ldots 1500$ мм.

Ключовим елементом нової ракети $\epsilon$ уніфікована багаторежимна ГСН, яка поєднує можливості пасивного інфрачервоного (тепловізійного), напівактивного лазерного та активного радіолокаційного наведення i здатна виявляти та розпізнавати різні цілі із застосуванням вбудованих алгоритмів за їх відео - та радіозображенням. Тепловізійний канал оснащується матрицею неохолоджуваних IЧ детекторів, розташованих у фокальній площині оптичної системи та забезпечують формування зображення цілі. Активний радіолокаційний режим роботи ГСН застосовуватиметься за поганих метеорологічних умов, а також в умовах пилу та диму на полі бою. Крім того, у комбінованій системі наведення УР на середній ділянці польоту використовується інерційна апаратура 3 радіокорекцією за даними космічної радіонавігаційної системи GPS. Також передбачається можливість здійснення корекції наведення та польоту ракети за інформацією, що надходить 3 інших зовнішніх джерел. Режими роботи можуть перемикатися в будь-якому порядку, виходячи із змін обстановки та застосуванням противником засобів протидії.

Переваги КР JAGM:

забезпечення системного вирішення досягнення високоточного ураження широкого спектру стаціонарних та рухомих цілей у будь-яких погодних умовах вдень та вночі;

надання ударним літакам, бойовим вертольотам та ударним БПЛА можливості контролю обстановки поза зоною огляду їх бортових засобів;

забезпечення ураження маневруючих захищених цілей типу бронетехніки, що рухається, або бронекатерів, а також важливих об'єктів в умовах щільної забудови міської інфраструктури;

перевага нової ракети над наявними аналогами за дальністю бойового застосування та вражаючою здатністю;

єдина ракета, що задовольняє тактикотехнічним вимогам різних видів ЗС, забезпечує багатофункціональність іï бойового застосування за мінімальних витрат обслуговування протягом усього життєвого циклу;

уніфікація елементів системи (ракет, контейнерів, пускових пристроїв, тренажноімітаційного і допоміжного обладнання) для різних видів 3С;

модульний принцип побудови із застосуванням відпрацьованих дешевих конструктивно-схемних рішень, висока надійність та низький технічний ризик проведення можливої модернізації. 
США приступили до дрібносерійного випуску нової КР JAGM у 2015 році, а прийняли ракету на озброєння - у 2016 році. Передбачалось, що на початковій стадії для потреб ЗС США придбають близько 35 тис. одиниць таких КР, а загальна кількість ракет, що закуповуються, може досягти 100 тис. Загальна вартість програми JAGM протягом наступних 25 років була оцінена на суму понад 7 млрд. дол. США. Передбачається, що новими ракетами будуть оснащені всі основні типи ударних літальних апаратів, що стоять на озброєнні всіх родів військ США - від багатоцільових літаків тактичної авіації типу F-35 та бойових вертольотів до ударних БПЛА. Єдина ракета JAGM повинна замінити існуючі КР даного класу, такі як "Хеллфайр", “Тоу” повітряного базування, сімейство УР “Мейверік” та інші.

\section{Висновки}

Отже, в даний час спостерігається тенденція зменшення калібру керованих ракет і КАБ, при цьому ї бойова ефективність не знижується, сумісний збиток зменшується, а кількість боєприпасів, що підвішується на один ЛА, значно збільшується. Крім того, керовані ракети малого калібру добре підходять для оснащення літаків як стратегічної бомбардувальної і тактичної авіації, так i бойових БпЛА, які на даний момент не розраховані на велике бомбове навантаження.

3 урахуванням досягнутого прогресу визначилися домінуючі тенденції у розвитку високоточних боєприпасів малого калібру, до яких, зокрема, можна віднести такі:

універсалізація та багатоваріантність бойового застосування високоточного авіаційного озброєння, модульний принцип побудови та уніфікація конструктивно-схемних рішень на всіх рівнях (функціональною, апаратурною, конструктивнотехнологічною та елементною), що дозволяють здешевити окремі зразки високоточного авіаційного озброєння для їх масового серійного виробництва.

\section{Список літератури}

1. Jane's Defence Equipment 2009-2010. (Электронная библиотека по вооружению и военной технике стран мира). [Electronic resource]. - Mode of acces: http:// books.google.com.ua/books/Jan_Infantry_Weapons_2009_2010.html.

2. Mulholland J., Bimstone. The Royal Air Force's New Precision Strike Weapon, Precision Strike Association Annual Programs Review, 18 Apr. 2006 [Electronic resource], - Mode of access: http://www.dtic.mil/ndia/2006psa_apr/mulholland.pdf.

3. Авиационные ПТУР зарубежных стран [Электронный ресурс]. - 2012. - Режим доступа: http://www.modernarmy.ru/article/140.

4. Ильин. С. Управляемое авиационное оружие малого калибра / С. Ильин // Зарубежное военное обозрение. [Electronic resource],-Mode of acces:http://pentagonus.ru/publ/upravljaemoe/aviacionnoe oruzhie_malogo_kalibra_2012/16-1-0-2338.

5. Перспективные технические решения и тенденции развития радиоэлектронных систем наведения для высокоточного оружия класса “воздух - поверхность” // В.А. Усачев [и др.] [Электронный ресурс]. - 2011. - Режим доступа: http://technomag.edu.ru/doc/245950.html.

6. UK Complex Weapons - Part 2 (Brimstone Missile) / Think Defence, April 11, 2013 [Electronic resource], - Mode of access: http://www.thinkdefence.co.uk/2013/04/uk-complex- weapons-part-1 -brimstone-missile.

7. Ракеты семейства MBDA Brimstone / Воен, обозрение, 26 мая 2014 г. [Электронный ресурс]. - 2014.- Режим доступа: http://topwar.ru/48840-rakety-semeystva-mbda-brimstone.html.

8. Joint Air-to-Ground Missile Affordable: Advanced, Air-launched, Precision Attack Missile. Raytheon Company Missile Systems Advanced Programs 1151 E [Electronic resource], - Mode of access: http://www.spacewar.com/reports/JAGM_Tri_Mode_Seeker_Demonstrated_Against_Moving_Sea_Targets_999.html.

9. Опытная многоцелевая управляемая ракета JAGM I Информационно-новостная система: ракетная техника [Электронный ресурс]. - 2014. - Режим доступа: http://rbase.new - factoria.ru/missile/wobb/jagm/jagm.shtml.

10. Raytheon's GBU-53 Small Diameter Bomb [Electronic resource], - Mode of access: http://www.defenseindustrydaily.com/Raytheon-Wins-USAs-GBU-53-Small-Diameter-Bomb-Compe-tition- 06510/.

11. SDB-II's Attack Modes: Seekers \& Sequences [Electronic resource], - Mode of access: http://www.defenseindustrydaily.com/raytheon-wins-usas-gbu-53-small-diameter-bomb-competition- 06510/.

12. GBU-53/B [Electronic resource], - Mode of access: http://z9.invisionfree.com/21c/ index.php?s= $7 \mathrm{~d} 7 \mathrm{cb} 2261 \mathrm{fd} 62483 \mathrm{f} 906 \mathrm{~b} 3 \mathrm{ed} 4 \mathrm{e} 0 \mathrm{~b} 63 \mathrm{e} 7 \&$ showtopic $=12128 \& \mathrm{st}=0$ \&\#entry22026307. 
Відомості про авторів:

\section{Серяков Ігор Ігорович}

старший науковий співробітник

Державного науково-дослідного інституту авіації, Київ, Україна

https://orcid.org/0000-0002-4618-5587

\section{Пономарьов Олександр Іванович}

старший науковий співробітник

Державного науково-дослідного інституту авіації, Київ, Україна

https://orcid.org/0000-0002-3814-2624

\section{Бабкін Сергій Іванович}

молодший науковий співробітник

Державного науково-дослідного інституту авіації, Київ, Україна

https://orcid.org/0000-0002-4463-6655

\section{Information about the authors:}

\section{Igor Suryakov}

Senior Researcher

of State Research Institute of Aviation, Kyiv, Ukraine

https://orcid.org/0000-0002-4618-5587

\section{Oleksandr Ponomarov}

Senior Researcher

of State Research Institute of Aviation, Kyiv, Ukraine

https://orcid.org/0000-0002-3814-2624

\author{
Serhii Babkin \\ Junior Researcher \\ of State Research Institute of Aviation, \\ Kyiv, Ukraine \\ https://orcid.org/0000-0002-4463-6655
}

\title{
MAIN TRENDS IN THE DEVELOPMENT OF AVIATION HIGH-PRECISION SMALL AMMUNITION AMMUNITION.
}

\author{
I. Suryakov, O. Ponamarov, S. Babkin
}

Thus, there is currently a tendency to reduce the caliber of KerR and KAB, while their combat effectiveness is not reduced, the concomitant damage is reduced, and the amount of ammunition suspended per aircraft is significantly increased. In addition, Kerr and small-caliber $C A B$ are well suited for equipping both strategic bomber and tactical aircraft, and combat UAVS, which are not currently designed for large-scale bombing.

Taking into account the progress made in various fields of materials science and modern technologies of electronics and photography, the dominant trends in the development of high-precision small caliber ammunition with multi-mode GOS, which include, in particular, include:

universalization and versatility of combat use of weapons equipped with similar GOS and combined guidance systems, due to the expansion of their capabilities;

modular principle of construction and unification of structural and circuit solutions at all levels (functional, hardware, structural and technological and elemental), which allow to reduce the cost of individual models of high-precision aircraft weapons for their mass production.

unification of system elements (missiles, containers, launchers, simulation and auxiliary equipment) for different types of weapons;

modular principle of construction with the use of proven cheap design and circuit solutions, high reliability and low technical risk of possible modernization.

Adopting the new generation of high-precision weapons discussed above can seriously change the balance of power on the battlefield. The fact is that most modern military air defense systems, which are supposed to protect military formations and point targets deployed on the battlefield, have a firing range of about $10 \mathrm{~km}$. A combat helicopter of the AN-64 "Apache" type, equipped with a JAGM missile launcher, can quite safely fire at air defense systems and objects, while also taking advantage of the terrain and folds of the terrain thanks to the principle of "fire and forget", that is, it came out from behind cover, fired rockets and hid again. In addition, a rather long drop range (up to $100 \mathrm{~km}$ ) and extremely small radar and infrared signatures of the $U A B G B U-53$ / B allow covert attacks on modern long and medium-range air defense systems, as well as any military air defense systems. To counter such weapons requires the joint and coordinated use of various air defense and electronic warfare systems capable of effectively suppressing both two-way communication channels and their multi-mode seeker in various ranges of the electromagnetic spectrum.

Keywords: combat aircraft, guided scorpion missile, combined guidance system, guided aviation bomb. 